\title{
Energy Requirement for Diazotrophic Growth of the Cyanobacterium Anabaena variabilis Determined from Growth Yields in the Dark
}

\author{
By BENT BORG JENSEN + \\ Institute of Biochemistry, Odense University, Campusvej 55, DK-5230 Odense M, Denmark
}

(Received 6 December 1982; revised 21 March 1983)

\begin{abstract}
The cyanobacterium Anabaena variabilis CCAP 1403/13a (UTEX 1444, ATCC 29413) was grown diazotrophically in the dark in the presence of fructose with a doubling time of $25 \mathrm{~h}$ at $35^{\circ} \mathrm{C}$. This was $40 \%$ of the maximum rate observed in the light. Growth rates in the dark were similar with nitrate or ammonium as nitrogen sources or under diazotrophic conditions. Darkgrown cyanobacteria reduced acetylene in the dark at $25 \%$ of the rate observed for photoautotrophic cultures in the light. Heterotrophic growth yields for dark growth with different nitrogen sources were estimated from the extent of fructose-dependent growth in batch cultures. The ratio between cell carbon and fructose carbon was 0.38 in diazotrophically grown cells, 0.38 with nitrate and 0.52 with ammonia. Thus the energy requirement for growth on molecular nitrogen is similar to the energy requirement for growth on nitrate, but greater than that for growth on ammonia. Since the diazotrophic culture always had a dissolved $\mathrm{O}_{2}$ concentration of at least $80 \%$ of air saturation, this demonstrates that there are no detectable extra energy requirements for aerobic nitrogen fixation compared to nitrate reduction, such as would result from a need for respiratory protection of nitrogenase.
\end{abstract}

\section{INTRODUCTION}

Cyanobacteria are generally considered to be photoautotrophic organisms. In recent years, however, several cyanobacteria have been shown to be capable of heterotrophic growth in the dark at the expense of various sugars which act as both carbon and energy sources. Most strains so far found capable of heterotrophic growth do so at only a small fraction of their photoautotrophic growth rate. A few of these cyanobacteria can also grow in the dark with $\mathrm{N}_{2}$ as the sole nitrogen source (Fay, 1965; Watanabe \& Yamamoto, 1967; Wolk \& Shaffer, 1976).

Heterocyst formation and nitrogen fixation are energy-demanding processes (Bradley \& Carr, 1977; Meyer et al., 1978). Energy is required for $N_{2}$ reduction and for the synthesis of extra components necessary for diazotrophic growth. Aerobic growth of free-living diazotrophic bacteria such as Azotobacter requires expenditure of energy to protect nitrogenase from inhibition by $\mathrm{O}_{2}$ (Robson \& Postgate, 1980). However, there is apparently no information available for cyanobacteria on the extra energy requirement for diazotrophic growth compared to the energy requirement for growth on other nitrogen sources.

In this paper, quantitative measurements are presented for dark growth and dark acetylene reduction by the cyanobacterium Anabaena variabilis, which is capable of heterotrophic growth under nitrogen fixing conditions (Wolk \& Shaffer, 1976). Dark diazotrophic growth is compared with dark growth on other nitrogen sources.

\section{METHODS}

Organism and growth conditions. The cyanobacterial strain used in this study was obtained as Anabaena flosaquae CCAP 1403/13a from the Culture Centre of Algae and Protozoa, Cambridge, U.K. It is generally agreed

† Present address: Department of Biochemistry, College of Agricultural and Life Sciences, University of Wisconsin-Madison, Madison, Wisconsin 53706, U.S.A. 
(Falkenberg et al., 1972; Booker \& Walsby, 1979) that the correct nomenclature for this strain [A-37 of Tischer (Tischer, 1965), UTEX 1444, ATCC 29413] is Anabaena variabilis and this name is used here.

The cyanobacteria were cultivated in the mineral medium of Allen and Arnon, as modified by Fay (1980), supplemented where appropriate with $10 \mathrm{~mm}$-fructose and buffered with $10 \mathrm{mM}$-HEPES/KOH, $\mathrm{pH} 7 \cdot 6$. They were grown at $35^{\circ} \mathrm{C}$ under continuous illumination provided by fluorescent tubes (Osram Fluora), which gave an incident photon flux rate of $50 \mu \mathrm{E} \mathrm{m}^{-2} \mathrm{~s}^{-1}$ between $400 \mathrm{~nm}$ and $700 \mathrm{~nm}$, or in the dark, in $100 \mathrm{ml}$ conical flasks containing $50 \mathrm{ml}$ medium, on a rotary shaker $(125$ r.p.m.). For growth in the dark flasks were wrapped with black plastic and aluminium foil. For acetylene reduction measurements the cyanobacteria were harvested in the exponential growth phase and resuspended in the growth medium without fructose. Unless otherwise stated this medium was used for all measurements.

Purity of the culture was confirmed by microscopic examination of stationary phase cultures and by plating on growth medium solidified with $1 \%(\mathrm{w} / \mathrm{v})$ agar and supplemented with $0.5 \%(\mathrm{w} / \mathrm{v})$ glucose and $0.05 \%(\mathrm{w} / \mathrm{v})$ Casamino acids.

Growth measurements. Growth was routinely measured by following apparent absorbance at $750 \mathrm{~nm}$ in Erlenmeyer flasks with side arms. Flasks were inoculated with cyanobacteria grown in the light plus fructose, corresponding to not more than $5 \mu \mathrm{g}$ dry weight. Since $A_{750}$ was not linearly dependent on cell concentration, the results are expressed as arbitrary units of biomass obtained from a calibration curve, or as dry weight using a conversion factor.

Total growth. $24 \mathrm{~h}$ after the cultures had reached stationary phase, total growth was measured as dry weight, packed-cell volume, chlorophyll $a$, biomass $\left(A_{750}\right)$ and total cell carbon.

Dry weight. Anabaena variabilis suspension $(10-20 \mathrm{ml})$ was washed once with distilled water by centrifugation, filtered on a predried glass fibre filter (Whatman GF/C), dried at $110^{\circ} \mathrm{C}$ for $2 \mathrm{~h}$, cooled in a desiccator and weighed.

Packed-cell volume. For packed-cell volume determinations $70 \mu \mathrm{l}$ microhaematocrit tubes were used and readings were taken after centrifugation for $5 \mathrm{~min}$ at $1000 \mathrm{~g}$.

Chlorophyll a. Samples $(1 \mathrm{ml})$ were extracted in $9 \mathrm{ml} 100 \%$ methanol for $10 \mathrm{~min}$. The concentration of chlorophyll $a$ was determined from the absorbance of the centrifuged extract at $665 \mathrm{~nm}$ using an absorption coefficient of $74.51 \mathrm{~g}^{-1} \mathrm{~cm}^{-1}$ (Mackinney, 1941).

Total cell carbon. Samples $(5 \mathrm{ml})$ of cell suspension were washed three times with $\mathrm{CO}_{2}$-free water and homogenized by passing through a syringe with a $0.5 \mathrm{~mm}$ diameter needle. Samples $(20 \mu \mathrm{l})$ of these suspensions were analysed for cell $\mathrm{C}$ using a Beckmann model 915 total organic carbon analyser linked to a Beckmann infrared analyser model 215 B. Malonic acid was used as standard.

CHN-determinations. Cells were washed three times with distilled water and dried for $2 \mathrm{~h}$ at $110^{\circ} \mathrm{C}$ before $\mathrm{CHN}$ determinations, which were made using a Hewlett-Packard Model 185 B CHN analyser. Acetanilide was used as standard.

Acetylene reduction. Nitrogenase activity was assayed by the acetylene reduction method (Turner \& Gibson, 1980). Anabaena variabilis suspensions ( $10 \mathrm{ml}$ containing $0 \cdot 2-0 \cdot 5 \mathrm{mg} \mathrm{dry} \mathrm{wt} \mathrm{ml}^{-1}$ ) were incubated under saturating illumination or in the dark at $35^{\circ} \mathrm{C}$ in $130 \mathrm{ml}$ bottles fitted with serum rubber stoppers. The gas phase was air with $10 \%(\mathrm{v} / \mathrm{v})$ acetylene. At appropriate time intervals, $0.5 \mathrm{ml}$ of the gas phase was withdrawn and ethylene concentration determined by gas chromatography using a Pye 104 gas chromatograph fitted with a flame ionization detector and a Porapak $\mathrm{R}$ column. The carrier gas was $\mathrm{N}_{2}$, with a flow rate of $20 \mathrm{ml} \mathrm{min}^{-1}$. Oven temperature was $50^{\circ} \mathrm{C}$.

Respiration rates. Rates of respiration were measured as $\mathrm{O}_{2}$ uptake in a closed system at $35^{\circ} \mathrm{C}$ using a Clark-type electrode (Hansatech Ltd, Kings Lynn, Norfolk, U.K.).

\section{RESULTS}

\section{Dark diazotrophic growth}

Typical growth curves for dark diazotrophic growth on fructose are shown in Fig. 1, together with curves for diazotrophic growth in the light plus fructose. Growth in the presence of fructose was exponential up to a level linearly dependent on the concentration of fructose. Continued growth under air in the light was linear and probably limited by $\mathrm{CO}_{2}$ diffusion. Table 1 shows growth rates of $A$. variabilis with various energy, carbon and nitrogen sources. Dark (chemoheterotrophic) growth in the absence of combined nitrogen occurred at $40 \%$ of the maximum rate observed in the light. Growth rates were similar with nitrate and under diazotrophic conditions.

Total growth in the dark under diazotrophic conditions increased linearly with the initial fructose concentration up to $40 \mathrm{~mm}$ (Fig. 2), whereas attempts to grow the cyanobacteria in the 


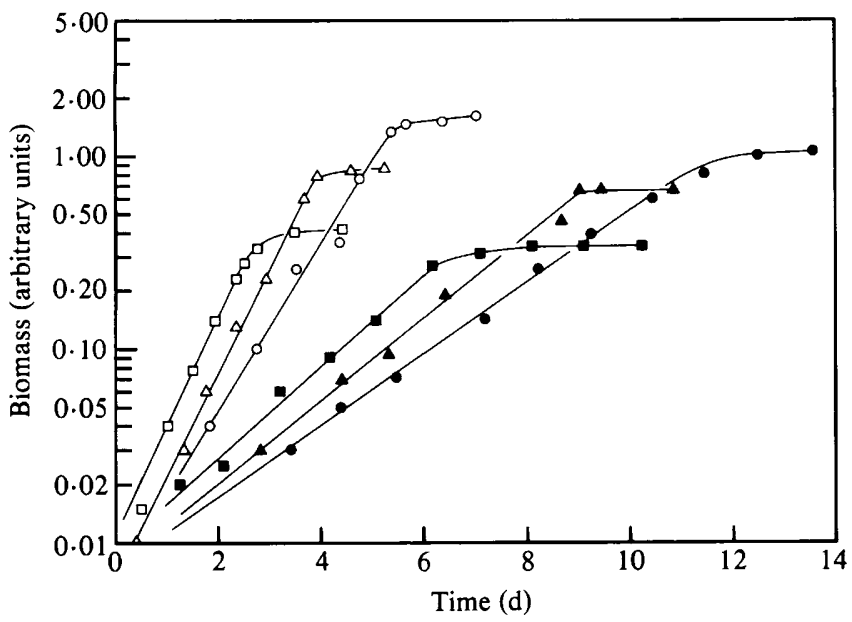

Fig. 1. Typical growth curves for $A$. variabilis. Cells were grown in batch cultures on a rotary shaker under $\mathrm{N}_{2}$-fixing conditions at $35^{\circ} \mathrm{C}$ in the light (open symbols) or dark (filled symbols). The medium contained fructose at $5 \mathrm{~mm}(\square, \square), 10 \mathrm{~mm}(\triangle, \Delta)$, or $20 \mathrm{~mm}(\bigcirc, \bigcirc)$. Growth was followed by measuring apparent absorbance at $750 \mathrm{~nm}$ in Erlenmeyer flasks with side arms and was converted to biomass using a calibration curve. Agitation was sufficient to maintain fully aerobic conditions. Other experimental details were as described in the text.

\section{Table 1. Growth rates of $A$. variabilis with various energy, carbon and nitrogen sources}

The gas phase was air except in the experiment where photoautotrophic growth (light plus $\mathrm{CO}_{2}$ ) was measured, where it was $1 \% \mathrm{CO}_{2}$ in air. Growth rate values are the means \pm S.D. of at least three independent experiments and are given as generation time (h).

\begin{tabular}{|c|c|c|c|c|c|}
\hline \multirow[b]{2}{*}{ Growth conditions } & \multirow{2}{*}{ 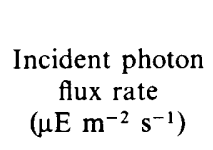 } & \multirow{2}{*}{$\begin{array}{l}\text { Fructose } \\
\text { concn } \\
(\mathrm{mM})\end{array}$} & \multicolumn{3}{|c|}{$\begin{array}{l}\text { Generation time }(h) \text { with } \\
\text { nitrogen source: }\end{array}$} \\
\hline & & & $\mathrm{N}_{2}$ & $\mathrm{NO}_{3}^{-}(10 \mathrm{~mm})$ & $\mathrm{NH}_{4}^{+}(10 \mathrm{~mm})$ \\
\hline \multirow[t]{3}{*}{ Chemoheterotrophic } & 0 & 5 & $25 \pm 3$ & $27 \pm 2$ & ND \\
\hline & 0 & 10 & $34 \pm 2$ & $34 \pm 4$ & $32 \pm 3$ \\
\hline & 0 & 40 & $40 \pm 1$ & $36 \pm 3$ & ND \\
\hline \multirow[t]{4}{*}{ Light plus fructose } & 25 & 10 & $14 \pm 1$ & $\overline{N D}$ & ND \\
\hline & 50 & 5 & $12 \pm 1$ & $13 \pm 2$ & ND \\
\hline & 50 & 10 & $14 \pm 1$ & $14 \pm 1$ & $14 \pm 2$ \\
\hline & 50 & 40 & $22 \pm 2$ & $16 \pm 1$ & ND \\
\hline Photoautotrophic & 50 & - & $18 \pm 1$ & $\mathrm{ND}$ & ND \\
\hline
\end{tabular}

ND, Not determined.

dark at initial fructose concentrations higher than $40 \mathrm{mM}(80,120$, and $160 \mathrm{~mm})$ failed. The growth rate in the dark decreased with increasing initial fructose concentration.

To ensure that the small amount of light to which the cyanobacteria were exposed during the absorbance measurements was not necessary for diazotrophic growth, an experiment was carried out in which cells were allowed to grow in Erlenmeyer flasks wrapped with black plastic and aluminium foil and then incubated in a totally dark room for $10 \mathrm{~d}$ without disturbance. The growth yields of these cultures were the same as those of the cyanobacteria used for growth rate measurements. Dark diazotrophic growth did not depend upon previous exposure to light, since A. variabilis could be grown in the dark for at least 30 generations.

Anabaena variabilis grown in the dark and in the light contained similar amounts of chlorophyll and phycobiliprotein on a dry weight basis. 


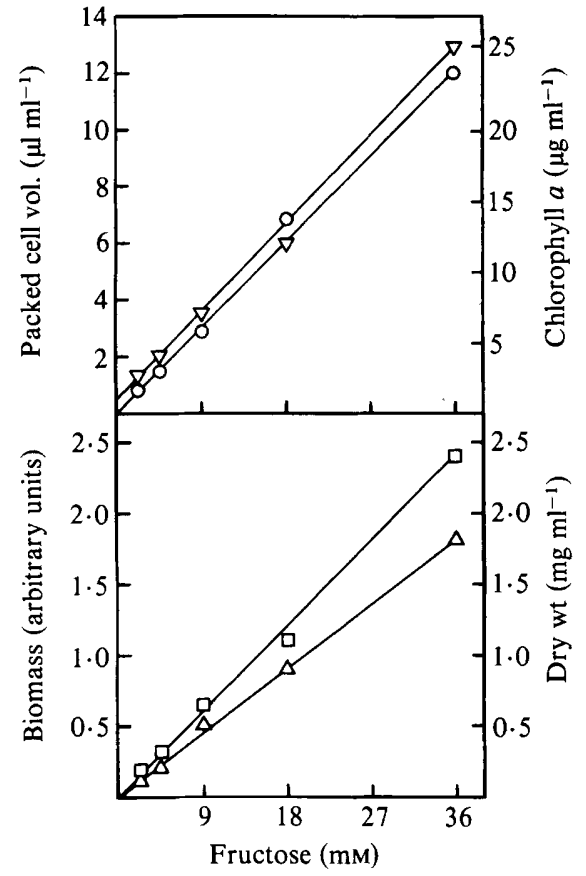

Fig. 2

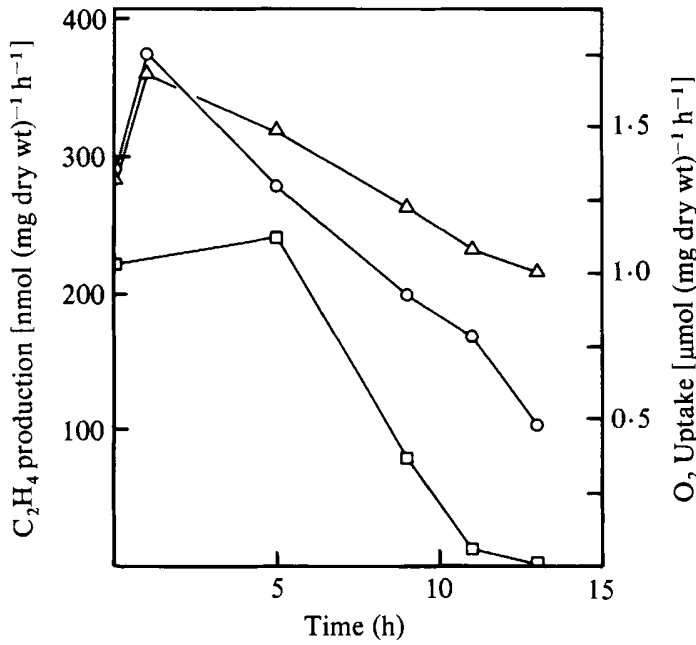

Fig. 3

Fig. 2. Effect of initial fructose concentration on total growth of $A$. variabilis in the dark. Cells were grown in batch culture under $\mathrm{N}_{2}$-fixing conditions on a rotary shaker at $35^{\circ} \mathrm{C}$. The initial inoculum corresponded to no more than $5 \mu \mathrm{g}$ dry weight. Total growth was measured $24 \mathrm{~h}$ after the culture had reached stationary phase. Other experimental details were as described in the text. $\square$, Biomass; $\nabla$, packed cell volume; $\triangle$, dry wt; $\bigcirc$, chlorophyll $a$.

Fig. 3. Changes in nitrogenase activity (acetylene reduction) and respiration in starved A. variabilis. Dark-grown cells were harvested in the exponential growth phase by centrifugation, resuspended in fresh growth medium without fructose and incubated in the dark at $35^{\circ} \mathrm{C}$. At appropriate time intervals, samples were taken and $\mathrm{C}_{2} \mathrm{H}_{2}$-reduction and $\mathrm{O}_{2}$-uptake were measured as described in Methods. $\square$, Ethylene production; $O$, endogenous respiration; $\triangle$, respiration with 2 mM-fructose.

\section{Acetylene reduction and respiration in dark-grown A. variabilis}

A capacity for dark diazotrophic growth requires the ability to fix $\mathrm{N}_{2}$ in the dark. Nitrogenase activities, measured as acetylene reduction rates, in light and darkness for cyanobacteria grown under various conditions are shown in Table 2 . The highest rates were obtained with cells grown in the light with fructose.

The rate of acetylene reduction in the dark remained constant as long as fructose was present in the growth medium (results not shown). When dark-grown cyanobacteria were transferred to fresh growth medium without fructose and incubated in the dark, the activity remained constant for at least $5 \mathrm{~h}$ and then declined, decreasing to zero after $13 \mathrm{~h}$ incubation (Fig. 3).

The rate of endogenous $\mathrm{O}_{2}$ uptake showed an initial increase and then declined following transfer to fructose-free medium in the dark (Fig. 3). Addition of fructose to the reaction medium caused a stimulation of $\mathrm{O}_{2}$ uptake, which reached a maximal rate within $1 \mathrm{~min}$ of addition. In contrast, inclusion of fructose in the incubation medium had no effect on the rate of acetylene reduction in short-term experiments $(30 \mathrm{~min})$. A range of sugars was tested for their capacity to stimulate respiration in cells starved for $24 \mathrm{~h}$ in the dark. Ribose, xylose, glucose, mannose, sucrose and maltose were ineffective or slightly inhibitory. Erythrose at a concentration of $1 \mathrm{~mm}$ caused a doubling of the rate of oxygen uptake. However, erythrose did not stimulate the rate of diazotrophic growth of $A$. variabilis in the light under an air atmosphere. 
Table 2. Rates of acetylene reduction in light and darkness by A. variabilis grown under various conditions

Cells were grown with $\mathrm{N}_{2}$ as nitrogen source, harvested in the exponential growth phase, and resuspended in growth medium without fructose at a concentration corresponding to $0 \cdot 2-0.5 \mathrm{mg}$ dry wt $\mathrm{ml}^{-1}$. Saturating illumination was with yellow light (Kodak Wratten 16 filter). Ethylene production at $35{ }^{\circ} \mathrm{C}$ was measured by gas chromatography. Other experimental details were as described in the text. The concentration of fructose was $10 \mathrm{mM}$ and of $\mathrm{CO}_{2}, 1 \%$. Values are the mean \pm S.D.of at least three independent experiments.

\begin{tabular}{|c|c|c|}
\hline \multirow[b]{2}{*}{ Growth conditions } & \multicolumn{2}{|c|}{$\begin{array}{l}\text { Acetylene reduction rate } \\
{\left[\mathrm{nmol}(\mathrm{mg} \text { dry } w \mathrm{t})^{-1} \mathrm{~h}^{-1}\right]}\end{array}$} \\
\hline & Light & Dark \\
\hline Photoautotrophic & $290 \pm 20$ & $90 \pm 20$ \\
\hline Light plus fructose & $910 \pm 40$ & $530 \pm 30$ \\
\hline Chemoheterotrophic & $470 \pm 60$ & $260 \pm 40$ \\
\hline
\end{tabular}

Table 3. Total growth, growth yield and elemental composition of A, variabilis grown with various nitrogen sources in the dark

The values are from batch cultures grown with an initial fructose concentration of $9 \mathrm{~mm}$. Total growth was measured $24 \mathrm{~h}$ after the culture had reached stationary phase. Growth yield was calculated from total growth and initial fructose concentration. Elemental composition was measured using cells harvested in exponential phase. Other experimental details were as described in the text. Values for total growth are mean \pm S.D. for at least three independent experiments.

\begin{tabular}{|c|c|c|c|c|c|c|c|c|}
\hline \multirow[b]{2}{*}{$\begin{array}{l}\text { Nitrogen } \\
\text { source }\end{array}$} & \multirow[b]{2}{*}{$\begin{array}{l}\text { Chlorophyll } a \\
\left(\mu \mathrm{g} \mathrm{ml}^{-1}\right)\end{array}$} & Total & owth & \multirow[b]{2}{*}{$\begin{array}{c}\text { Cell C } \\
\left(\mathrm{mg} \mathrm{ml}^{-1}\right)\end{array}$} & \multirow{2}{*}{$\begin{array}{l}\text { Growth yield } \\
\text { [g dry wt (mol } \\
\text { fructose })^{-1} \text { ] }\end{array}$} & \multicolumn{3}{|c|}{$\begin{array}{c}\text { Elemental } \\
\text { composition }(\%)\end{array}$} \\
\hline & & $\begin{array}{c}\text { (arbitrary } \\
\text { units) }\end{array}$ & $\begin{array}{c}\text { Dry wt } \\
\left(\mathrm{mg} \mathrm{ml}^{-1}\right)\end{array}$ & & & C & $\mathrm{H}$ & $\mathrm{N}$ \\
\hline $\mathrm{N}_{2}$ & $6 \cdot 1 \pm 0.5$ & $0.60 \pm 0.06$ & $0.54 \pm 0.07$ & $0.25 \pm 0.02$ & 59 & $42 \cdot 6$ & $7 \cdot 1$ & $9 \cdot 6$ \\
\hline $\mathrm{NO}_{3}^{-}$ & $6 \cdot 1 \pm 0 \cdot 4$ & $0.62 \pm 0.05$ & $0.54 \pm 0.05$ & $0.25 \pm 0.02$ & 59 & $44 \cdot 2$ & $7 \cdot 2$ & $10 \cdot 2$ \\
\hline Urea & $6 \cdot 1 \pm 0.2$ & $0.62 \pm 0.06$ & $0.59 \pm 0.04$ & $0.24 \pm 0.02$ & 63 & ND & ND & ND \\
\hline $\mathrm{NH}_{ \pm}^{+}$ & $8.3 \pm 0.6$ & $1.01 \pm 0.03$ & $0.73 \pm 0.07$ & $0.35 \pm 0.02$ & 79 & ND & ND & ND \\
\hline
\end{tabular}

ND, Not determined.

\section{Dark growth yields with different nitrogen sources}

Dark growth with $\mathrm{N}_{2}$ as nitrogen source was compared with growth in the dark in the presence of several sources of combined nitrogen. Table 3 shows total growth and growth yields obtained with $A$. variabilis grown aerobically in the dark in media containing $9 \mathrm{~mm}$-fructose and various nitrogen sources. Growth yield was calculated from total growth and the initial fructose concentration. Growth yields were similar with nitrate, urea and $\mathrm{N}_{2}$ as nitrogen sources, but higher with ammonia. Aerobic conditions were confirmed by measuring $\mathrm{O}_{2}$ concentration polarographically. Late-exponential phase cultures $\left(0.4-0.5 \mathrm{mg}\right.$ dry wt $\left.\mathrm{ml}^{-1}\right)$ were found to have a dissolved $\mathrm{O}_{2}$ concentration corresponding to $80 \%$ of air saturation $(175 \mu \mathrm{M})$.

While cells grown with nitrate or ammonia did not produce heterocysts and so lost their capacity to reduce acetylene, urea-grown $\boldsymbol{A}$. variabilis contained a few heterocysts and reduced acetylene both in light and darkness at about one third of the rate of the $\mathrm{N}_{2}$-grown cyanobacteria.

Also shown in Table 3 are the carbon, nitrogen and hydrogen contents of $A$. variabilis grown diazotrophically and in the presence of nitrate. The elemental compositions were very similar with about $10 \% \mathrm{~N}$ by weight and $43 \% \mathrm{C}$ by weight. The molar $\mathrm{C} / \mathrm{N}$ ratios were 5.1 for diazotrophically grown cells and 4.9 for those grown with nitrate. From the cell carbon determinations it was calculated that $52 \%$ of the added carbon was converted to cell carbon in the ammonia-grown cells while only $38 \%$ was converted to cell carbon in the cultures grown on nitrate or molecular nitrogen. 


\section{DISCUSSION}

Apart from the rough estimate reported by Wolk \& Shaffer (1976) for Anabaena variabilis, molar growth yields for diazotrophic cyanobacteria do not appear to have been reported. Our measurements of the growth yield of $A$. variabilis grown on fructose in the dark gave a value for $Y_{\text {fructose }}$ of $54 \mathrm{~g}$ dry wt (mol fructose) $)^{-1}$ for diazotrophically grown cells. This value can be compared with those reported for Azotobacter chroococcum (Dalton \& Postgate, $1969 a, b$ ). However, a major difference is that Azotobacter, unlike Anabaena, is apparently unable to grow diazotrophically at dissolved $\mathrm{O}_{2}$ concentrations in the medium much above $20 \mu \mathrm{M}$ (Robson \& Postgate, 1980). The growth yield reported by Dalton \& Postgate $(1969 a, b)$ at low dilution rates where respiratory protection would be significant was $8 \mathrm{~g}$ dry wt (mol mannitol) $)^{-1}$, which is much lower that that found here for $A$. variabilis. Under conditions close to the optimum where the need for respiratory protection is less, the growth yield reported for Azotobacter $445 \mathrm{~g}$ dry wt (mol mannitol $)^{-1}$ ] approaches that observed with $A$. variabilis. The values for the ammoniagrown and nitrate-grown $A$. variabilis are similar to values reported by Bottomley $\&$ van Baalen (1978) for the cyanobacterium Nostoc Mac, which does not fix $\mathrm{N}_{2}$, and to the values reported for other aerobic bacteria grown on the same nitrogen sources (Stouthamer, 1976).

The growth yield in terms of chlorophyll reported here $[0.68 \mathrm{mg}$ chlorophyll $a$ (mol fructose $)^{-1}$ ] is slightly lower than that reported for the same strain for growth in the dark at $30^{\circ} \mathrm{C}$ [0.8 mg chlorophyll $a$ (mol fructose) ${ }^{-1}$ ] by Wolk \& Shaffer (1976).

The efficiency of nitrogen fixation is often expressed as $\mathrm{mg} N$ fixed ( $\mathrm{g}$ carbon source consumed) ${ }^{-1}$. Jensen (1954) estimated efficiencies of $10-15 \mathrm{mg} \mathrm{N}$ (g carbon source) ${ }^{-1}$ for Azotobacter from measurements made with batch cultures. Dalton \& Postgate $(1969 \mathrm{~b})$ found efficiencies between 30 and $40 \mathrm{mg} \mathrm{N}$ fixed ( $\mathrm{g}$ carbon source) ${ }^{-1}$ for chemostat cultures of Azotobacter chroococcum at low oxygen concentrations. Since $10 \%$ of the dry weight of $A$. variabilis was nitrogen (Table 3), the amount of nitrogen fixed corresponds to $33 \mathrm{mg} \mathrm{N}$ ( $\mathrm{g}$ fructose $)^{-1}$, which is similar to the value reported for Azo. chroococcum. Again it should be noted that the value for $A z o$. chroococcum was measured at a low dissolved oxygen concentration, while that for $A$. variabilis was measured at an $\mathrm{O}_{2}$ concentration correponding to $80 \%$ of air saturation.

From the rate of acetylene reduction, using a conversion factor for $\mathrm{C}_{2} \mathrm{H}_{4} / \mathrm{N}_{2}$ of four for these cyanobacteria (Jensen \& Cox, 1983) a specific rate of $0.019 \mathrm{~g} \mathrm{~N}$ fixed ( $\mathrm{g}$ cell N$)^{-1} \mathrm{~h}^{-1}$ was found, which correlates very well with the value for the specific growth rate of $0.020 \mathrm{~h}^{-1}$.

Growth yields with nitrate and $\mathrm{N}_{2}$ as nitrogen sources were similar. This demonstrates that there are no detectable extra energy requirements for aerobic nitrogen fixation compared to nitrate reduction. Such requirements would result from a need for respiratory protection of nitrogenase, as found in Azotobacter (Dalton \& Postgate, 1969b). There seems to be common impression that the ATP requirement for nitrogen fixation is large compared to the ATP requirement for nitrate reduction but, as pointed out by Postgate \& Cannon (1981), this is not the case. One can write a general equation for nitrogen fixation:

$$
\mathrm{N}_{2}+4 \mathrm{NADPH}+6 \mathrm{H}^{+}+12 \mathrm{ATP} \rightarrow 2 \mathrm{NH}_{4}^{+}+\mathrm{H}_{2}+12 \mathrm{ADP}+4 \mathrm{NADP}^{+}
$$

This equation follows the mechanism proposed by Chatt (1980) which involves obligatory production of $\mathrm{H}_{2}$ by nitrogenase to yield a minimum $\mathrm{H}_{2} / \mathrm{N}_{2}$ ratio of 1 . We have recently shown that the $\mathrm{N}_{2} / \mathrm{H}_{2}$ ratios observed in $A$. variabilis are in excellent agreement with this mechanism (Jensen \& Cox, 1983). To calculate the energy requirement in terms of ATP equivalents, to the $12 \mathrm{~mol}$ ATP used by the nitrogenase complex one must add the $12 \mathrm{~mol}$ ATP that could have been generated from the $4 \mathrm{~mol}$ NADPH by oxidative phosphorylation (at a $\mathrm{P} / \mathrm{O}$ ratio of three). Thus, $12 \mathrm{~mol}$ ATP equivalents are used for the production of $1 \mathrm{~mol} \mathrm{NH}_{4}^{+}$.

For nitrate reduction one can write a corresponding general equation:

$$
\mathrm{NO}_{3}^{-}+4 \mathrm{NADPH}+6 \mathrm{H}^{+} \rightarrow \mathrm{NH}_{4}^{+}+4 \mathrm{NADP}^{+}+3 \mathrm{H}_{2} \mathrm{O}
$$

The energetic cost of this reaction is the $12 \mathrm{~mol}$ ATP that could have been generated from the $4 \mathrm{~mol} \mathrm{NADPH}$ used for the production of $1 \mathrm{~mol} \mathrm{NH}_{4}^{+}$(again assuming a $\mathrm{P} / \mathrm{O}$ ratio of 3). Thus as biochemical processes, nitrogen fixation and nitrate reduction can occur with the expenditure of identical amounts of energy [see Postgate \& Cannon (1981) for further discussion]. 
The decrease in molar growth yield on replacing ammonia by $\mathrm{N}_{2}$ as nitrogen source can be used to calculate the apparent energy requirement for nitrogen fixation in vivo. In the following calculation it is assumed that the energy requirements for metabolic processes, other than those involved in nitrogen fixation, were similar under the two types of growth conditions. The carbon conversion efficiency was found to be $0.52 \mathrm{~g}$ cell C ( $\mathrm{g}$ fructose $\mathrm{C})^{-1}$ for ammonia-grown cells and $0.38 \mathrm{~g}$ cell $\mathrm{C}$ ( $\mathrm{g}$ fructose $\mathrm{C})^{-1}$ for diazotrophically grown cells. Carbon balance studies (results not shown) suggested that the remaining fructose was oxidized to $\mathrm{CO}_{2}$ and water. This corresponds to $0.013 \mathrm{~mol}$ fructose oxidized $(\mathrm{g} \text { cell C) })^{-1}$ for ammonia-grown cells, and $0.023 \mathrm{~mol}$ fructose oxidized ( $\mathrm{g}$ cell C) $)^{-1}$ for the diazotrophically grown cells. The extra energy requirement for diazotrophic growth is thus $0.010 \mathrm{~mol}$ fructose $(\mathrm{g} \text { cell } \mathrm{C})^{-1}$. Since the $\mathrm{C} / \mathrm{N}$ ratio of the cyanobacteria was 4.3 by weight this corresponds to 0.043 mol fructose ( $\mathrm{g} \mathrm{N}$ fixed) $)^{-1}$ or $1.20 \mathrm{~mol}$ fructose (mol $\mathrm{N}_{2}$ fixed) $)^{-1}$.

This value can be converted to an $\mathrm{ATP} / \mathrm{N}_{2}$ ratio if the $\mathrm{P} / \mathrm{O}$ ratio is known. The oxidative pentose phosphate cycle is the major and possibly only route for carbohydrate metabolism in cyanobacteria (Doolittle, 1979). Taking a value of three, the oxidation of $1 \mathrm{~mol}$ of fructose by the pentose phosphate pathway corresponds to the formation of $35 \mathrm{~mol}$ ATP. This gives an ATP/N molar ratio of 42 . This value is higher than the theoretical value of 24 . An explanation for this could be that the amount of ATP generated from fructose oxidation is overestimated as the result of the choice of a $\mathrm{P} / \mathrm{O}$ ratio of three. $\mathrm{P} / \mathrm{O}$ ratios in intact cyanobacteria vary between 0.6 and 2.9 depending on the growth medium and the assay conditions (Nitschmann \& Peschek, 1982). Similar variations were observed for heterotrophic bacteria (Stouthamer \& Bettenhaussen, 1973). Assuming that the $\mathrm{P} / \mathrm{O}$ ratio is two as found by Nitschmann \& Peschek (1982) for Anacystis nidulans grown in normal medium, then the theoretical and measured ATP $/ \mathrm{N}_{2}$ ratios of 20 and $26 \mathrm{~mol} \mathrm{ATP} / \mathrm{N}_{2}$, respectively, are in reasonable agreement with each other.

In conclusion, the results presented here suggest that heterocystous cyanobacteria have the potential capacity for diazotrophic growth in the dark in the presence of higher dissolved oxygen concentrations than other heterotrophic bacteria without intracellular differentiation, such as azotobacters. The protection provided by heterocysts against inactivation of nitrogenase by oxygen (Gallon, 1981) may also remove the need for respiratory protection at intermediate dissolved $\mathrm{O}_{2}$ concentrations with a resulting low efficiency of conversion of substrate into cell carbon.

The author wishes to thank Martin Svendsen for skilled technical assistance, and Dr Raymond P. Cox for his constant advice and encouragement during the course of the work and for his critical reading of the manuscript.

\section{REFERENCES}

Booker, M. J. \& WalsBY, A. E. (1979). The relative form resistance of straight and helical blue-green algal filaments. British Phycological Journal 14, 141150.

Bottomley, P. J. \& Van BaAlen, C. (1978). Characteristics of heterotrophic growth in the blue-green alga Nostoc sp. strain Mac. Journal of General Microbiology 107, 309-318.

Bradley, S. \& CARR, N. G. (1977). Heterocyst development in Anabaena cylindrica: the necessity for light as an initial trigger and sequential stages of commitment. Journal of General Microbiology 101, 291-297.

ChatT, J. (1980). Chemistry relevant to the biological fixation of nitrogen. In Nitrogen Fixation, pp. 1-18. Edited by Stewart, W. D. P. \& Gallon, J. R. London: Academic Press.

Dalton, H. \& Postgate, J. R. (1969a). Effect of oxygen on growth of Azotobacter chroococcum in batch and continuous cultures. Journal of General Microbiology 54, 463-473.
Dalton, H. \& Postgate, J. R. (1969 b). Growth and physiology of Azotobacter chroococcum in continuous culture. Journal of General Microbiology 56, 307-319.

Doolittle, W. F. (1979). The cyanobacterial genome, its expression, and the control of that expression. Advances in Microbial Physiology 20, 1-102.

Falkenberg, P., Buckland, B. \& Walsby, A. E. (1972). Chemical composition of gas vesicles isolated from Anabaena flos-aquae. Archiv für Mikrobiologie 85, 304-309.

FAY, P. (1965). Heterotrophy and nitrogen fixation in Chlorogloea fritschii. Journal of General Microbiology 39, 11-20.

FAY, P. (1980). Heterocyst isolation. Methods in Enzymology 69, 801-812.

Gallon, J. R. (1981). The oxygen sensitivity of nitrogenase: a problem for biochemists and microorganisms. Trends in Biochemical Sciences 6, 19-23.

JeNSEN, H. L. (1954). The Azotobacteriaceae. Bacteriological Reviews 18, 195-214.

Jensen, B. B. \& Cox, R. P. (1983). Direct measure- 
ments of steady state kinetics of cyanobacterial $\mathrm{N}_{2}$ uptake using membrane-leak mass spectrometry, and comparisons between nitrogen fixation and acetylene reduction. Applied and Environmental $\mathrm{Mi}$ crobiology 45, 1331-1337.

MaCKINNEY, G. (1941). Absorption of light by chlorophyll solutions. Journal of Biological Chemistry 140, 315-322.

Meyer, J., Kelley, B. C. \& Vignais, P. M. (1978). Effect of light on nitrogenase function and synthesis in Rhodopseudomonas capsulata. Journal of Bacteriology 136, 201-208.

NitschmanN, W. H. \& Peschek, G. A. (1982). Oxidative phosphorylation in intact cyanobacteria. FEBS Letters 138, 77-80.

Postgate, J. R. \& Cannon, F. C. (1981). The molecular genetic manipulation of nitrogen fixation. Philosophical Transactions of the Royal Society of London, Series B 292, 589-599.

Robson, R. L. \& Postgate, J. R. (1980). Oxygen and hydrogen in biological nitrogen fixation. Annual Review of Microbiology 34, 183-207.

Stouthamer, A. H. (1976). Yield Studies in Microorganisms. Durham: Meadowfield Press.

Stouthamer, A. H. \& Bettenhaussen, C. (1973). Utilization of energy for growth and maintenance in continuous and batch cultures of microorganisms. Biochimica et biophysica acta 301, 53-70.

TiSCHER, G. R. (1965). Pure culture of Anabaena flosaquae A 37. Nature, London 205, 419-420.

Turner, G. L. \& Gibson, A. H. (1980). Measurement of nitrogen fixation by indirect means. In Methods for Evaluating Biological Nitrogen Fixation, pp. 111138. Edited by F. J. Bergersen. Chichester: Wiley. Watanabe, A. \& Yamamoto, Y. (1967). Heterotrophic nitrogen fixation by the blue-green alga Anabaenopsis circularis. Nature, London 214, 738.

Wolk, P. C. \& Shaffer, P. W. (1976). Heterotrophic micro- and macrocultures of a nitrogen-fixing cyanobacterium. Archives of Microbiology 110, 145-147. 